\title{
Numbers 748 and 749 of The French and Polish Version of Catechism of the Catholic Church from the Translational Perspective; an Example of the Theological Effects of Translation
}

This article considers the art of translation through a comparative analysis of the translations of two selected theological texts taken from the French and Polish version of the Catechism of the Catholic Church (CCC). Specifically, this study examines the Polish and French versions of CCC 748, which speaks about the relationship between the Church and Christ. As CCC 749 reveals, this relationship, pertains not only to the Second Person of the Holy Trinity, but also to the Third Person, meaning the Holy Spirit. Like the number that precedes it, CCC 749 is translated differently in both the Polish and French versions. Essentially, this article highlights the difficulty of translating and demonstrates how difficult it is to translate and how responsible the translator is for his translations of theological texts that pertain to faith.

Key words: Christ, Holy Spirit, Catholic Church, ecclesiology, translation, Catechism of the Catholic Church, theological language, art of translation.

The Catechism of the Catholic Church (CCC), ${ }^{1}$ which John Paul II promulgated to the entire Church in 1992, is the fruit of the work of 
many people who spent several years working together to systematically present the Catholic Church's teachings on faith and morals. The CCC is a compendium that was compiled and adapted based on the needs and mentality of modern man. This systematic exposition Catechetics of the faith, which was published more than 25 years ago, could not omit teachings on the Church. The ecclesiology presented in the CCC provides modern man with a true image of the Church, which is organically connected with the Holy Spirit. The CCC may be particularly useful for those who understand the Church only in an external way as a sacred building, a hierarchical institution, or a social and financial institution that is linked to politics. Those who ascribe to such a view of the Church often begin to feel dislike, disgust, hostility, and even rebelliousness against what they perceive to be the Church's conservatism and "flaws," which leads them to pit the Church against Christ by saying: "Christ—yes, the Church—no." Such "contraposition arises in some way due to the complexity of our act of faith, which bids us to say "Credo [...] Ecclesiam." ${ }^{3}$ It is for this particular reason, therefore, that the CCC also includes a reflection on ecclesiology under this same title.

Before providing a basic lesson on the Church in CCC 748, 749, and 750 and as part of their introduction to ecclesiology, however, the authors of the CCC attempt to explain to the reader the basic truths contained in the article of faith on the Church, and how this article depends on the articles of faith concerning the Son and the Holy Spirit. The analysis of the aforementioned passages from the CCC that follows will demonstrate that the explanations in the French version of the text differ from the explanations provided in the Polish version. The analytical and comparative reflections of these passages in the Polish and French versions, which will also refer to the Latin topical edition as well as the English, Italian, and Russia editions of the CCC, will demonstrate that "in order to translate well and correctly, every translator must meet certain conditions-namely, sufficient knowledge of the original language, thorough knowledge of the language into which a work is to be translated, and knowledge of the subject matter. These conditions also apply to those who translate doctrinal texts. The correctness of the translation does not depend solely on the

Roma 1993 (hereafter abbreviated as CCCI); Катехизис Католической Церкви, Moskwa 1996 (hereafter abbreviated as CCCR); and Catechismus Catholicae Ecclesiae, Roma 1997 (hereafter abbreviated as CCCL). 
translator, however. Rather, the secret of a good translation, meaning the translated text's compatibility with the original, also lies in the languages themselves." 4

The context of CCC 748 and 749, which provide a somewhat general introduction to ecclesiology, serve as a source of reflection on the art of translation of doctrinal texts and not as an attempt to systematically discuss the Church's teaching on the Church itself, since the Catechism already does this. This article is divided into two parts, which discuss the relationship between Christ and the Church as well as the Holy Spirit and the Church, respectively. Although points 748, 749, and 750 serve as a kind of introduction to the section of the CCC dedicated to the topic of ecclesiology and should be analyzed together, this analysis will not consider CCC 750 because its content is very rich and the translation issues pertaining to what is meant by the Latin expression "Credo... Ecclesiam" presented in the passage are complex and deserve to be examined in a separate study.

\section{Christ and the Church}

In CCC 748, where the authors speak about the doctrine on the Church, they point out to the reader the interdependence that exists between the article of faith on the Church and the articles that pertain directly to Jesus Christ. ${ }^{5}$ In the very first sentence of CCC 748, however, which states, "Chrystus jest światłem narodów; obecny Święty Sobór, zgromadzony w Duchu Świętym, gorąco pragnie oświecić wszystkich ludzi Jego jasnością promieniującą na obliczu Kościoła, głosząc Ewangelię wszelkiemu stworzeniu," ["Christ is the light of humanity; and it is, accordingly, the heart-felt desire of this sacred Council, being gathered together in the Holy Spirit, that, by proclaiming his

$4 \quad$ L. M. Jakoniuk, The French and Polish Versions of the Catechism of the Catholic Church: An Examination of Certain Passages of the Catechism's teaching on the "Mysterium Ecclesiae" from a Philological and Translational Perspective, RTK XVI/3 (2017), pg. 320 .

5 "'Christ is the light of humanity; and it is, accordingly, the heart-felt desire of this sacred Council, being gathered together in the Holy Spirit, that, by proclaiming his Gospel to every creature, it may bring to all men that light of Christ which shines out visibly from the Church.' These words open the Second Vatican Council's Dogmatic Constitution on the Church in the Modern World: Lumen Gentium. By choosing this starting point, the Council demonstrates that the article of faith about the Church depends entirely on the articles concerning Christ Jesus. The Church has no other light than Christ's; according to a favorite image of the Church Fathers, the Church is like the moon, all its light is reflected from the sun" (CCCE 748). 
Gospel to every creature, it may bring to all men that light of Christ which shines out visibly from the Church"], ${ }^{6}$ there is a certain methodological inconsistency. Although the editors of the CCC enclosed the words taken from the Dogmatic Constitution on the Church in Catechetics quotation marks, which would suggest that they are quoting directly (ad litteram) from what is contained in the Dogmatic Constitution on the Church in the Modern World: Lumen Gentium, ${ }^{7}$ they do not provide any references in the text itself or in the footnotes, which they do include in both versions of the text (Polish and French) in other points of this section. ${ }^{8}$ Moreover, even if this was not a direct quotation, but rather a paraphrase of what is contained in the Lumen Gentium, the authors of the CCC should have pointed this out in a footnote just as they did with other paraphrased biblical texts, citing from where the given thought comes. ${ }^{9}$ Not only the Polish and French versions of the CCC, but also the Russian and Italian versions do not directly reference the conciliar documents in CCC $748 .{ }^{10}$ The English and Latin versions of

6 'Le Christ est la lumière des peuples: réuni dans l'Esprit Saint, le saint Concile souhaite donc ardemment, en annonçant à toutes créatures la bonne nouvelle de l'Evangile, répandre sur tous les hommes la clarté du Christ qui resplendit sur le visage de l'Eglise" (CCCF 748); "Lumen gentium cum sit Christus, haec sacrosancta Synodus, in Spiritu Sancto congregata, omnes homines claritate Eius, super faciem Ecclesiae resplendente, illuminare vehementer exoptat, omni creaturae Evangelium annuntiando" (CCCL 748).

The Polish, French, and Latin versions of the CCC quote the text word for word: "[...] Tymi słowami rozpoczyna się Konstytucja Dogmatyczna o Kościele Soboru Watykańskiego II” (CCCP 748); “[...] C'est sur ces paroles que s'ouvre la «constitution dogmatique sur l'Eglise» du deuxième Concile du Vatican [...]" (CCCF 748); "[...] His verbis aperitur «Constitutio dogmatica de Ecclesia» Concilii Vaticani II [...]" (CCCL 748).

See, for example: CCCP 894; CCCP 947; and CCCP 949, as well as CCCF 773; CCCF 871; and CCCF 884.

In point 19 of the prologue of the $\mathrm{CCC}$, the authors state that the texts of the Sacred Scripture are not quoted word for word and are merely indicated in the footnotes. Because of this, the reader can always refer back to the biblical texts, which will help him or her to understand a given passage better. In addition, in this same point, the authors remark that "Such biblical references are a valuable working-tool in catechesis." Por. CCCP 19; see, for example, the footnotes for CCCP 139-147, pg. 191.

10 The absence of a reference in these translations could indicate that the authors of the aforementioned versions followed the French translation of the CCC too closely and reproduced the same error. See CCCR 748 and CCCI 748. 
the CCC are more methodologically precise, however, and do include references to the Council document in point $748 .{ }^{11}$

Moreover, the Polish version of the conciliar document, which is quoted here in the CCC is of interest because there are doubts regarding its source. The passage from Lumen Gentium contained in CCC 748 of the Polish version is not an exact quotation from the version of conciliar documents published in Polish, ${ }^{12}$ to which the authors of the CCC refer in the first few pages of the Catechism. ${ }^{13}$ In addition, the translation of the passage from the Lumen Gentium contained in CCC 748 is also an inaccurate translation of the French version of the same passage. Both instances primarily point out the apparent differences between the Polish passage of this conciliar document and how it is presented in the Polish version of the CCC,${ }^{14}$ as well as some of the differences between the Polish and the French versions of this

Here, the CCCE went further than the CCCL by providing additional information-namely, the translators of the CCCE included the citation from the Holy Bible (i.e., Mk 16:15), which points out to the reader of the CCCE the specific sources of the ideas and thoughts contained in these sentences. Thus, when compared to other translations of the CCC, the CCCE translates number 748 better than the other translations by providing additional information. See footnote 120 in CCCL (p. 209) and footnote 135 in CCCE (p. 172).

This also is not a quotation taken directly from the Latin-Polish text of the Council documents, which were published in Paris in 1967. See: Second Vatican Council: Dokumenty, Dekrety, Deklaracje. Tekst łacińsko-polski., Paris 1967, pgs. 78-79.

13 "Cytaty z dokumentów soborowych wzięto z: Sobór Watykański II: Konstytucje, Dekrety, Deklaracje, Pallottinum 1968, wydanie I" CCCP, pg. 4. Quotations from conciliar documents appear not only in this point of the CCC, but also in other places of this same part of the CCC, which does not indicate that the authors of the Polish version of the CCC quoted these passages directly from their sources (see, for example, the citations contained in: CCCP 757 and the Lumen Gentium 6; CCCP 759 and Lumen Gentium 2; CCCP 764 and Lumen Gentium 5). This does not mean, however, that quotations in this entire section of the CCC come from the published Polish translations of the conciliar documents. Apart from the examples quoted above, there are points in the CCC's section on ecclesiology that contain quotations that differ in no way and are reproduced exactly from the official Polish translations of the conciliar texts published in 1968 (see, for example: CCCP 918 and Perfectae Caritatis 1; CCCP 937 and Christus Dominus 2; CCCP 873 and Apostolicam Actuositam 2).

When the passage of interest from Lumen Gentium is quoted in the CCC, several versions shift the word order in different expressions. For example, "Sobór Święty" is changed to "Święty Sobór;" "w Duchu Świętym zgromadzony" is changed to "zgromadzony w Duchu Świętym;" "pragnie gorąco" is reversed as "gorąco pragnie." Morever, in the cited text the translators left the conjunction "ponieważ" and they replaced the noun "blask" with "jasność" as well as the adjective "jaśniejący" with the feminine adjective "promieniująca." These 
text. ${ }^{15}$ Based on the Polish version of the Lumen Gentium and what is contained in the original French version, the quotation contained in CCC 748 of the Polish version appears to be comprised of a compilation of both sources. During the translation process, the Polish translators probably benefited from the French translation to a greater or lesser degree, which undoubtedly aided them in the translation of this particular excerpt. ${ }^{16}$

Although the text from the Lumen Gentium was not cited in the Polish and French versions of the CCC, and although the Polish version of the quote is not a direct quotation from the Polish edition of the conciliar documents, it does contain one verbal difference-namely, the fact that the French word "resplendir"17 is translated into Polish using the adjectival form of the Polish verb "promieniować" (to radiate). There is a difference between these two words that becomes clearer when one considers how Christ is compared to the sun and the Church is compared to the moon in this passage of the CCC. The French verb "resplendir" works very well in this analogy. It indicates that the Church (moon) is unable to emit its own light; instead, its splendor is due to Christ (sun), who light is reflected in the "face" of

changes reveal how the French version of the CCC influenced the Polish translation. See Lumen Gentium 1; CCCP 748.

Unlike the Polish version, the French version lacks the adjective "present," which, in the Polish text, was used in relation to the Council. In addition, the French expression "la bonne nouvelle de l'Evangile" was translated into Polish using the noun "Ewangelia [Gospel]," which is a shorter expression. These differences suggest that, in this instance, the translators could have based the Polish text on the Council documents. See CCCF 748; CCCP 748; Lumen Gentium 1.

16 Unlike the Polish edition of the CCC, the typical edition faithfully quoted the original text, which was edited by the conciliar fathers, in point 748. See CCCL 748, Sobór WatykańskiII:Dokumenty, Dekrety, Deklaracje. Tekstłacińsko-polski, Paris 1967, pg. 78.

17 As the dictionaries state, this verb appears in the sense "briller avec un grand éclat." In Polish, the verbs "błyszczeć, lśnić, odbijać blask" can be used. In Latin, the French equivalent of this word is the verb "resplendere" (to reflect, to shine), which was also used in the Latin passage from Lumen Gentium included in point 748 of the typical edition of the CCC ("super faciem Ecclesiae resplendente"). Por. CCCL 748; Dictionnaire des noms communs, des noms propres, précis de grammaire, Paris Larousse 1993, "resplendir," pg. 575; Dictionnaire du français, Hachette 1987, "resplendir," pg. 1374; Dictionnaire du poche français-polonais et polonais-français, ed. B. Hamel, Warsaw n.d., "resplendir," pg. 154; Podręczny stownik francusko-polski, ed. K. Kupisz and B. Kielski, Warsaw 1993', "resplendir," pg. 750; Stownik tacińsko-polski, ed. M. Plezia, vol. 4, Warsaw, PWN, 1974, "resplendere," pg. 538. 
the Church (moon). ${ }^{18}$ In this context, the literal meaning of the Polish verb "promieniowac" [radiate] ${ }^{19}$ does not really correspond with the comparison made in CCC $748,{ }^{20}$ since it is usually used in Polish in a different way. ${ }^{21}$ Therefore, a when a Polish reader sees the verb "promieniować," he may not have a clear understanding of the metaphor relating Christ and the Church as a French reader who sees the verb "resplendir." In this instance, the Latin, Russian, English, and Italian versions ${ }^{22}$ of the CCC used verbs that are closer in meaning

$18 \quad$ As S. Gądecki states "The metaphor of light [...] may have appeared because of the observation of the simple succession from day to night." The theme of light appears rather often in the Holy Scriptures. Among its many meanings (truth, life), it serves primarily as a symbol for God's presence. Light serves as His "robe" when He appears to people (Exod 24:17; Ps 97:3n; Ps 104:2; Ez 43:2; Mt 17:2; Acts 9:3). Luke 2:32 uses the phrase from Isaiah "a light to the nations" (49:6) to refer directly to Christ, and John 8:12 states the following about Christ Himself: "I am the light of the world. Whoever follows Me will not walk in darkness, but will have the light of life." See K. H. Schelkle, Teologia Nowego Testamentu. Bóg byt w Chrystusie, vol. 2, Cracow 1984, pgs. 298-303; S. Gądecki, Wstęp do Pism Janowych, Gniezno 1996², pg. 52.

Strictly speaking, the Polish verb "promieniować" means the phenomenon of emittance of radiant, thermal, light, or electromagnetic energy, which in French is conveyed using verbs other than "resplendir" (e.g., rayonner, irradier), depending on the meaning. Stownik języka polskiego, ed. M. Szymczak, vol. 2, Warsaw 19927, "promieniować,” pg. 936; Stownik poprawnej polszczyzny, ed. W. Doroszewski, Warsaw 1980, "promieniować," pg. 572; Podręczny słownik polsko-francuski, K.Kupisz, B. Kielski, Warsaw 19939, “promieniować,” pg. 561.

As C. Bartnik states, as early as the beginning of the $3^{\text {rd }}$ century, ideas in the Church such as "a holy gathering" or "convention" changed to images taken from daily life. These new images included likening the Church to a Woman, a Mother-Virgin who gives new life; nourishes the faithful through the revealed word, faith, and the sacraments; and protects and prepares the faithful for eternity (Hermas, St. Cyprian, St Irenaeus). According to Origen, the Church is like the moon (mysterium lunae), and Christ is like the sun. Por. C. S. Bartnik, Kościót Jezusa Chrystusa, Wroclaw 1982, pg. 31.

The French verb "resplendir" literally means the action of reflecting light, while the Polish word "promieniować" basically means the phenomenon of secreting (emitting) energy from oneself through some kind of object. The authors of the Stownika poprawnej polszczyzny [Dictionary of Proper Polish] listed some instances in which it is possible to use this word: for example, "rad promienuje [radium emits]," "piec promieniował ciepłem [the stove radiated heat]." Stownik poprawnej polszczyzny, ed. W. Doroszewski, Warsaw 1980, "promieniować," pg. 572.

In the Russian text, this verb is translated using the adjective "сияющий," which in Polish is translated as "błyszczący, lśniący" (сияние - blask, połysk, jasność, światło) and "сиять," which in Polish means "świecić, błyszczeć, połyskiwać, jaśnieć, lśnić." The English version of the CCC uses the word "shine" in this instance, while the Italian edition uses the verb "riflettere." Podręczny stownik rosyjsko-polski, ed. 
than the Polish to the French verb "resplendir." If the Polish translators used the Polish verb "jaśnieć,"23 for example, where the French used "resplendir," then this choice certainly would have been closer in meaning to the French and would have better conveyed the essence Catechetics of the image contained in CCC 748-one that is "a favorite image of the Church Fathers." ${ }^{24}$ The differences in the translations of CCC 748 do not end here, however.

Later in CCC 748, it is clear how the Polish translation departs from the original French version of the CCC. For example, the Polish translators reversed the word order of the last two words of the following passage: "Sobór wskazuje w ten sposób, że artykuł wiary o Kościele całkowicie zależy od artykułów dotyczących Jezusa Chrystusa" [the Council demonstrates that the article of faith about the Church depends entirely on the articles concerning Jesus Christ]. ${ }^{25}$ Here, the last two words "Jezusa Chrystusa" [Jesus Christ] are in the reverse order of the French version "le Christ Jésus." ${ }^{26}$ The Italian editors of the CCC translated the final two words of this sentence in the exact same way as the Polish translators. ${ }^{27}$ This slightly different rendering in Polish was most likely due to the fact that the expression "Jesus Christ" use to be used much more frequently in the past. ${ }^{28}$ This, therefore, is most

J. H. Dworecki, Warsaw 1986, “сияние,” pg. 711; Langenscheidt's pocket english dictionary english-polish polish-english, ed. T. Grzebieniowski; Maty słownik włosko-polski i polsko wtoski, ed. S. Soja, C. Zawadzka, Z. Zawadzki, Warsaw 1977, "riflettere," pg. 279.

The Polish translators of the conciliar documents used this word as a rendering of the Latin verb "resplendere," which occurs at the beginning of Lumen Gentium. The equivalent of the word "jaśnieć" in Polish-French dictionary is, among other things, the verb "resplendir." Podręczny stownik polsko-francuski, K.Kupisz, B. Kielski, Warsaw $1993^{9}$, pg. 208. The fact that this word was translated as "promieniować" in the Polish version of CCC 748 suggests once again that the translators of the Polish edition did not use an exact quotation from the Polish edition of the conciliar documents in this instance. See Lumen Gentium 1. Podręczny stownik polsko-francuski, K. Kupisz, B. Kielski, Warsaw $1993^{9}$, pg. 208.

CCCP 748.

CCCP 748.

"Par là, le Concile montre que l'article de foi sur l'Eglise dépend entièrement des articles concernant le Christ Jésus [...]” (CCCF 748).

"Con cio il Concilio indica che l'articolo di fede sulla Chiesa dipende interamente dagli articoli concernenti Gesu Cristo [...]" (CCCI 748).

"[...] najczęstszy na Wschodzie i upowszechniony na Zachodzie porządek to «Jezus Chrystus»." Historia dogmatów. Bóg zbawienia, ed B. Sesboué and J. Woliński, vol.1, Cracow 1999, pg. 100. 
likely the reason why the Polish editors chose not to pay attention to the French version and, instead, translate the expression in the reverse order. The reversal of the word order still had implications for the French version of the text. For, there was a discrepancy in the meaning of the word "Christ" in both versions of the text. ${ }^{29}$ In French, Catechetics the expression "le Christ Jésus" is used as a title for Christ, which is evident in the use of the definite article " $l e " 30$ as well as the placement of "le Christ" before the word "Jésus" 31 In the Polish text, the meaning

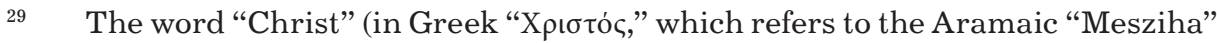
and the Hebrew "Masziah," meaning "anointed") in contrast to "Jesus" (in Greek "Inбovc" and in Hebrew "Yeshua" or "Yehoshua," meaning "God saves") is not a personal name, but rather a title that denotes a mission, or the description of an office. As J. Sesboué states, it is "the title of the Lord's Anointed One or the Messiah, Shepherd, and eschatological Savior." In the Sacred Scripture, the word often appears in connection with the personal name Jesus. Although he also used the expression "Jesus Christ" (Rom 7:24), Paul was very fond of the expression "Christ Jesus." This expression seems archaic and, therefore, is rarely used. E. Dąbrowski, "Jezus Chrystus," in Podręczna encyklopedia Biblijna, ed. E.Dąbrowski, vol. 1, Poznan 1959, pg. 549; Stownik Nowego Testamentu, ed.X.L. Dufour, Poznan 1981, "Jezus Chrystus," pgs. 312-318; Stownik teologii biblijnej, ed. X. L. Dufour, Poznan-Warsaw 1982, “Jezus Chrystus,” pgs. 347-357; Historia dogmatów. Bóg zbawienia, eds. B. Sesboué and J. Woliński, vol.1, Cracow 1999, pg. 100.

30 If the French editors of the CCC considered the word "Christ" a second name for Jesus, then they would not have included the word "le" before "Christ" because, according to French grammar, an article is not used before a name (P. Wrzosek, Język francuski od A do Z. Repetytorium, Warsaw 1995, pg. 22). Therefore, in this case, the article explicitly indicates the function of the expression in the text; the article determines the meaning word "Christ." As B Kielski points out, in French the article is used as "a means to analytically determine the meaning of words. French language can use different kinds of articles to determine every noun (or concept) to varying degrees according to the analysis of the thought. [...] in French, the article is a very flexible determinant that is lacking in Polish. In order to properly determine a noun or concept [in Polish], it is necessary to either use more weighted expression or simply (and most often) default to the closer determination." The same phenomenon occurs in the Greek text of the New Testament when the disciples saw Jesus as the promised Messiah and called him "the Christ" (see Mt 16:16; Jn 20:31[NTG] as well as $[\mathrm{LBF}])$. In these instances, the Greek and French texts use the article. When the article is not present, then it means that the word "Christ" is being used as Jesus' second name. B. Kielski, Struktura języków francuskiego i polskiego $w$ świetle analizy porównawczej, vol. 1, Lodz 1957, pg. 60; C. Focant, "Christ," in Stownik Biblijny, Brepolis 1987, pg. 268; J. T. Nelis i A. Lacocque, "Messie," in Stownik Biblijny, Brepolis 1987, pgs. 820-821.

31 In Sacred Scripture, both the expression "Jesus Christ," the second word of which is first used in the earliest writings of the New Testament as the second name of Jesus, and "Christ Jesus" appear. The latter is also used in some of St.

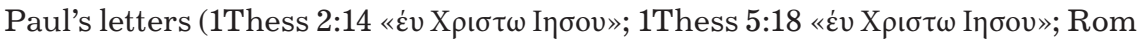


of this expression is not as clear as in the French version of the CCC. In the Polish version, the word "Chrystus" appears to serve simply as the second part of Jesus' name. In addition, the second word "Chrystus" is absorbed by the first word "Jezus" in such a way that, as the Catechetics authors of the Dictionary of Biblical Theology state, "unjustly maims the Gospel." 32 Apart from the Italian version, the editors of the other language versions of the CCC exercised more caution and faithfully followed the French version, ${ }^{33}$ thereby conveying the proper meaning of the expression "le Christ." When comparing the French and Polish versions of CCC 748, unlike the Polish readers, French readers immediately realize (due to the analytical character of the French language ${ }^{34}$ ) that the expression concerns not the name of Jesus Christ, but rather "Jesus called the Messiah" as the subject of faith. ${ }^{35}$

\section{The Holy Spirit and the Church}

As mentioned above, the authors of the Catechism of the Catholic Church point out the ongoing relationship between the article on the Church and the articles on Jesus Christ. CCC 749 focuses on the latter. In the first sentence of CCC 749, the editors of the French and Polish versions of the CCC both emphasize the complete interdependence between CCC 749 and CCC 748, which covers the topic of the Holy Spirit. ${ }^{36}$ The interdependence that the CCC points out is not a new teaching in the doctrine on the Church. The Roman Catechism points out the relationship between the Holy Spirit and the Church in its commentary on this article on the Church. The authors of the current Catechism

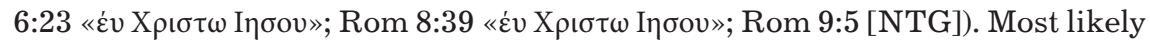
Paul used this expression to emphasize that "Christ" acts more as a title than a name. J. A. Fitzmyer, "Mesjasz," in Encyklopedia Biblijna, ed.P. J. Achtemeier, Warsaw 1999, pgs. 739-741.

Stownik teologii biblijnej, ed . X. L. Dufour, Poznan-Warsaw 1982², "Jezus Chrystus," pg. 347.

The arrangement "Christ Jesus" was used in the Russian, English, and Latin versions of the CCC. See CCCR 748; CCCE 748; and CCCL 748.

In this case, this analytical feature is evident primarily in the wording: "le Christ Jésus."

36 This thought is reflected in old confessions of the faith that speak about the Church in connection with the Holy Spirit. The Apostolic Symbol also speaks of the Church as the first work of the Holy Spirit that comes before the "communion of saints, the forgiveness of sins, the resurrection of the body, and life everlasting." 
used this passage of the document and cited it in the second sentence of CCC 749: "Indeed, having shown that the Spirit is the source and giver of all holiness, we now confess that it is he who has endowed the Church with holiness.' The Church is, in a phrase used by the Fathers, the place "where the Spirit flourishes." 37 The passage quoted in both the Polish and French versions of the CCC demonstrates how both the Polish and French versions do not correspond with each other in this instance. ${ }^{38}$ More specifically, although both language versions refer to the same passage from the Roman Catechism, ${ }^{39}$ which is evident in the footnote contained in both translations, ${ }^{40}$ the Polish translation of CCC 749 differs from both the French and Latin translations.

In particular, there is a difference between the Polish adjective "absolutny" [absolute] and the French word "donateur." The former appears only in the Polish version of the CCC, while the latter appears only in the French version of the CCC. The adjective "absolutny," which does not appear in the French version of the text, was used by the Polish translators with regard to the Holy Spirit who "ukazuje sie jako absolutne źródło wszelkiej świętości" [appears as the absolute source of all holiness] (CCC 749). Clearly, the Polish editors used the adjective "absolutny" to modify the noun "źródło" [source], which generally has several meanings. ${ }^{41,42}$ Within the context of CCC 749 ,

$37 \quad$ CCCP 749.

38 "En effet, après avoir montré que l'Esprit Saint est la source et le donateur de toute sainteté, nous confessons maintenant que c'est Lui qui a doté l'Eglise de sainteté" (CCCF 749).

39 The original text contained in the Roman Catechism, which is included in both versions of the CCC, reads: "Pendent autem hic articulus a superiori, quia cum iam demonstratum sit, Spiritum Sanctum omnis sanctitatis fontem et largitorem esse, nunc ab eodem Ecclesiam sanctitate donatam confitemur." Catechismus Romanus ex decreto Concilii Tridentini ad Parochos, Bielefeld 1859, pg. 79.

See footnote 98 in the CCCP (pg. 187), as well as footnote 1 in the CCCF (pg.165).

41 Usually, in both Polish and French the noun "źródło" [source] has three meanings. First, both languages define it as the location where a natural outflow of underground water comes to the surface of the earth; the beginning of a river or a stream. Second, the word means "where something originates, begins; that which is the beginning of something." Third, this word usually means "materials that serve as a means of knowledge in some area, which is the foundation for further research, studies, etc.” Słownik języka polskiego, ed. M. Szymczak, vol. 3, Warsaw 19927, “źródło," pg. 936; Por. Larousse de poche. Dictionnaire des noms communs, des noms propres, precis de grammaire, Paris 1993, "source," pg. 625; Dictionnaire du français, Hachette 1987, "source," pg. 1491.

42 As the Polish dictionaries convey, the noun "absolut" [absolute] comes from Latin (absolutus-zupełny, bezwzględny). The word, therefore, indicates something 
the word "absolutny" can mean several things depending on how the reader interprets it. Some readers might interpret the word to have a philosophical meaning and, therefore, conclude that the authors of Polish version of the CCC wanted to emphasize the divine and perCatechetics fect nature of the source-that is, that the Holy Spirit in Himself is the source that "is completely holy by His very divine nature." ${ }^{43}$ Still other readers might interpret "absolutny" to have a colloquial meaning and understand it as a synonym for "wytaczny" [exclusive], "zupetny" [total], "catkowity" [complete], or "jedyny" [only], which are used more often on a daily basis than the adjective "absolutny." This is likely what the Polish authors had in mind when they were editing CCC 749. The Italian version of the CCC also reflects the same kind of interpretation on the part of its authors who translated this passage in a way similar to the Polish version. ${ }^{44}$ Rather than using the Italian word "assoluto," ${ }^{45}$ as was used in the Polish text, however, the Italian translators used the word "totale" [total], ${ }^{46}$ which is colloquial and does not sound as academic as the adjective "absolute." In this passage, the Polish version of the CCC is decidedly closer to the Italian version in its choice of wording than the French version. This similarity suggests that the Polish editors relied exclusively on the Italian version of the CCC in this

that is total, complete, utter, without exception, without reservation. In science it is possible to encounter this word in different expressions: for example, absolute zero, absolute temperature, absolute geometry, absolute hearing, etc. See Słownik języka polskiego, ed. M. Szymczak, vol. 1, Warsaw 19927, "absolutny," pg. 3. In philosophy, the word "absolute" is used to describe a being that is independent of all other beings, without a cause, unlimited, perfect, and generally understood as unchanging, eternal, and the only and necessary basis of reality on which everything else depends. Por. Stownik wyrazów obcych, Warsaw 1978, "absolut-absolutny," pg. 2-3.

Por. Y. De Andia, "Święty, Pan, Dawca życia," in Communio 8(1988) no. 1, pgs. 36-39.

"L'articolo sulla Chiesa dipende anche interamente da quello sullo Spirito Santo, che lo precede. "In quello, innfatti, lo Spirito Santo ci appare come la fonte totale di ogni santita; in questo, il divino Spirito ci appare comme la sorgente della santita della Chiesa»" (CCCI 749).

As the Stownik Wtosko-Polski [The Polish-Italian Dictionary] points out, this word can first be translated in Polish as "absolutny" and then as "bezwzględny," "samowładny," and "zupełny." As examples of how the word "absolutely" applies in Italian, the authors include: "vuoto assoluto" [próżnia absolutna], "zero assoluto" [bezwzględne zero]. Clearly, these are purely academic expressions. See Maty stownik wtosko-polski i polsko wtoski, eds. S. Soja, C. Zawadzka, Z. Zawadzki, Warsaw 1977, (assoluto), pg. 31.

46 In Polish, the words "ogólny," "zupełny," and "całkowity" are equivalents of the Italian adjective "totale." See ibid, “totale,” pg. 350. 
instance, and not on the French version. This is highly likely because the Italian version of the $\mathrm{CCC}$ was published earlier than the Polish version, ${ }^{47}$ and, therefore, was accessible to the Polish translators.

The French noun "donateur" appears both in the French version of the CCC as well as the typical version. ${ }^{48}$ The best equivalent of this in Polish is the word "dawca" [giver]. Both in French and in Polish, the semantic field of these expressions is similar. ${ }^{49}$ In French and Polish, this word can indicate both a person and the action of giving, bestowing, or selflessly imparting something to another person out of love..$^{50}$ In the French version of the CCC, the authors use the word "donateur" [giver] as a name for the Holy Spirit, just as the Polish editors used the word "źródło" [source] as a name for the Holy Spirit. Just as the concept "źródło" points to the cause of holiness, the expression "dawca" shows the manner in which this holiness is conveyed. When used in reference to the Holy Spirit, both terms "źródło" and "dawca" complement each other. After all, the Spirit of God cannot sanctify if He were not holy Himself. ${ }^{51}$ Calling the Holy Spirit a giver is rather suggestive. This expression is continued later in this same sentence in French through the use of the verb "doter" [endow], which in Polish means "wyposażać" [equip], "obdarzać" [bestow]. ${ }^{52}$ Both French words, "donateur" and "doter," which are used in CCC 749 correspond to the Holy Spirit very well, since He is, after all, the "Giver of gifts" as the

47 Ten language versions of the CCC were published in its first year of publication, including the Italian version. M. Napieralski, O nowym Katechizmie. Wprowadzenie w lekturę Katechizmu Kościoła Katolickiego, Poznan 1994, pgs. 40-41.

In addition to the aforementioned versions of the CCC, the English and Russian versions contain words equivalent to the French expression "donateur": "[...] the Spirit is the source and giver of all holiness" (CCCE 749) and "[...] Дух Святой есть источник и даритель всякой святости (CCCR 749).

49 See Stownik języka polskiego, ed. M. Szymczak, vol. 1, Warsaw 19927, "dawca," pg. 362; Larousse de poche. Dictionnaire des noms communs, des noms propres, precis de grammaire, Paris 1993, "donateur," pg. 206; Dictionnaire du français, Hachette 1987, “donateur,” pg. 492.

50 "Now, the reason of donation being gratuitous is love; since therefore do we give something to anyone gratuitously forasmuch as we wish him well" (Summa Theologiae, I, q. 38, a. 2). Quoted in: John Paul II, Wierzę w Ducha Świętego Pana i Ożywiciela, Vatican City 1992, pg. 283.

$51 \quad$ Por. J. Szymusiak, Duch Święty w Kościele wedtug Ojców Kościoła trzech pierwszych wieków, AK, 65 (1973) 1, pg. 56.

52 See K. Kupisz, B. Kielski, Podręczny słownik francusko-polski z suplementem, Warsaw 19939, “doter,” pg. 241. 
liturgical sequence sung on Pentecost states. ${ }^{53}$ Moreover, when the word "dawca" is used to indicate the Holy Spirit's personal involvement in the process of sanctifying man, it also implies the freedom that accompanies this involvement. He who is the Giver-the Holy Catechetics Spirit-and is the source of man's sanctity approaches man to offer him a gift; the Holy Spirit never "enslaves" man. There is freedom wherever the Spirit of the Lord is. ${ }^{54}$ As a result, this holiness becomes "a dialogic reality that is similar to love or friendship" 55 between the giver and recipient.

The aforementioned differences indicate that it is unlikely that the Polish translators of the CCC relied on the French version or a direct source such as the Roman Catechism when working on CCC 749 . Rather, in this instance, the Polish version of the CCC resembles the Italian version. The presence of the adjectives "absolutny" and "totale" in relation to the word "źródło" in the Polish and Italian versions of the CCC, respectively, confirms this fact. In addition, the fact that both Polish and Italian versions of the CCC do not use the French noun "donateur" speaks to the fact that the Polish text relied on the Italian version in this instance. Because the Polish authors omitted the word "dawca" in the Polish version, they failed to convey the full meaning of CCC 749. By speaking of the Holy Spirit only as the source, the Polish version of this passage does not convey to Polish readers the fullness of the image of the Holy Spirit that the French version conveys. In this instance, likening the Holy Spirit to a source and giver has a richer and important meaning. The Third Person of the Most Holy Trinity is not a typical or ordinary source; He is the Spirit-Giver "from which derives as from its source (fons vivus) all giving of gifts vis-a-vis creatures (created gift)." 56 In addition to the fact that the Polish version did not include the word "dawca" [giver] in CCC 749, the entire sentence structure and the use of such expressions as "absolutne źródto" [absolute source] or "bijace źródto świętości Kościoła" [the beating source of the Church's holiness], leave much to be desired. Unlike the formulations used in other versions of the CCC, those used in the Polish version do not help the reader to better understand the meaning CCC 749. In this regard, the French version of CCC 749 is translated

53 Por. Dominum et Vivificantem 67; John Paul II, Wierzę w Ducha Świętego Pana i Ożywiciela, Vatican City 1992, pg. 267.

Por. 2 Cor 3:17.

E. Ozorowski, Wierzę w Ducha Świętego, Bialystok 1998, pg. 13.

Dominum et Vivificantem 10. The symbol of the "living water," which refers directly to the Holy Spirit, appears in John 7:38-39. 
much better because it is much simpler in its form and diction and, consequently, closer to the Latin version of the CCC. In order to help Polish readers understand the meaning of CCC 749 as it was written in French and translated into the typical version, the Polish should have read as follows: "Artykuł o Kościele całkowicie zależy także od artykułu o Duchu Świętym, który go poprzedza. «W rzeczywistości, po ukazaniu, że Duch Święty jest źródłem i dawcą wszelkiej świętości teraz wyznajemy, że to On obdarzył Kościól świętością» [...]” [“The article concerning the Church also depends entirely on the article about the Holy Spirit, which immediately precedes it. 'Indeed, having shown that the Spirit is the source and giver of all holiness, we now confess that it is he who has endowed the Church with holiness." $].{ }^{57}$ If CCC 749 sounded this way, then it certainly would have helped Polish readers to better understand the relationship between the article of faith on the Holy Spirit and the article on the Church.

\section{Conclusion}

Lawrence Venuti's ${ }^{58}$ contemporary theories on translation distinguish two models of translation: the instrumental and the hermeneutic. The former concerns what in Polish is most often expressed by the verb "przektadać" (transfer, translate, shift). To translate the text from one language to another as an ongoing process is considered an imitative act wherein the role of the translator is to overcome the language barrier, meaning to express in the second language what is understood in the first (original) language. The latter model is that which is understood in Polish in the word "ttumaczyc" (translate), which results in an interpretation of the original text. In this way, according to the hermeneutic model, the translator subjectively assumes, interprets, and clarifies the meaning of the original text. Unlike the instrumental model, the hermeneutic model assumes that new translations of texts are always necessary because the context in which the reader receives and understands the original text is constantly changing ${ }^{59}$. The French and Polish passages analyzed above serve as an example of how the

57 "Articulus de Ecclesia etiam plene ab illo de Spiritu Sancto dependet qui eum praecedit. «Quia cum iam demonstratum sit Spiritum Sanctum omnis sanctitatis fontem et largitorem esse, nunc ab Eodem Ecclesiam sanctitate donatam confitemur»" (CCCL 749).

58 For more on the contemporary concepts of translation see: P. Bukowski, M. Heydel, Wspótczesne teorie przekładu. Antologia, ed., Cracow 2009.

59 See: M. Črnivec, Theology of translation. An introductory inquiry http://www. academia.edu/1779339/Theology_of_Translation (21.08.2018) 
work of translation is difficult on its own when one does not even consider the fact that translating from Polish to French, which both have different etymologies (the former is a Slavic language, while the latter is a Romance language) and vice versa entails its own problems. ${ }^{60}$ At

Catechetics certain moments, the translator's presence is very discrete and even imperceptible, so much so that the reader can perceive the translator's presence only when imperfections in the translation occur. At other times, the translator comes to the fore and assumes a "central" place in the translation of the text when the translator interprets and explains the text in his own way by using a particular vocabulary or syntax. As, Fr. Prof. Lucjan Balter, SAC points out, the problem with preparing the Polish version of the CCC arises from the fact that,

by having the French version of the Jerusalem Bible as well as the French renderings of the writings of the Fathers of the Church (Sources Chr.) at their disposal, the editors of the CCC drew from them large amounts of text [...] which was not possible to do in any other translation [of the CCC] into another language. ${ }^{61}$

Moreover, after the CCC was published, Cardinal Ratzinger announced that the Latin version would serve as the "typical" edition. For this reason, translators of the Polish version, on the one hand, "occasionally" treated the French version as the guiding and authoritative text and, on the other hand, strove to convey what was contained in the French version. In some ways, this explains why both the instrumental and hermeneutic approaches to translation can be found in the Catechism of the Catholic Church.

\section{FRANCUSKA I POLSKA WERSJA PUNKTÓW 748 I 749 KATECHIZMU KOŚCIO ŁA KATOLICKIEGO Z PERSPEKTYWY TRANSLATORSKIEJ. TEOLOGICZNE NASTĘPSTWA TŁUMACZEŃ}

Niniejszy artykuł jest próbą analizy porównawczej z perspektywy sztuki translatorskiej dwóch wybranych teologicznych tekstów z wersji francuskiej i polskiej Katechizmu Kościoła Katolickiego. Zauważone uwagi, co do wersji polskiej i francuskiej Katechizmu, zgrupowane zostały wokół 748 punktu KKK,

60 Por. M. Kaczyński, Ttumaczenie różnych form rzeczowników polskich na język francuski, Lublin 2000, pg. 11.

61 L. Balter, Letter written to Leszek Jakoniuk on November 19, 1998 (private archive). 
który w swej treści wskazuje czytelnikowi na relację, jaka zachodzi między Kościołem i Chrystusem. Jednak należy zauważyć, że powyższa zależność nie ogranicza się wyłącznie do artykułów wiary dotyczących Drugiej Osoby Trójcy Świętej, lecz także dotyka Trzeciej Osoby Boskiej, jaką jest Duch Święty. O tym mówi Katechizm w punkcie 749, który podobnie jak poprzedni punkt nie uchronił się przed różnicami, jakie zaszły między jego wersją francuską a polską. Artykuł pokazuje jak trudna i odpowiedzialna jest praca tłumacza zwłaszcza, kiedy problem przekładu dotyka tekstów teologicznych związanych z wiarą.

Słowa kluczowe: Chrystus, Duch Święty, Kościół, eklezjologia, tłumaczenie, Katechizm Kościoła Katolickiego, język teologii, sztuka przekładu.

\section{Bibliography:}

1. Balter L., Letter to L. Jakoniuk, November 19, 1998.

2. Bartnik C. S., Kościót Jezusa Chrystusa, Wroclaw 1982.

3. Bukowski P., Heydel M., Wspótczesne teorie przektadu. Antologia, Cracow 2009.

4. Catechism of the Catholic Church, London 1994.

5. Catéchisme de l'Eglise Catholique, Mame Librairie Editrice Vaticane, Paris 1992.

6. Catechismo Della Chiesa Cattolica, Rome 1993.

7. Catechismus Catholicae Ecclesiae, Rome 1997.

8. Catechismus Romanus ex decreto Concilii Tridentini ad Parochos, Bielefeld 1859.

9. Črnivec M., Theology of translation. An introductory inquiry http://www. academia.edu/1779339/Theology_of_Translation (21.08.2018)

10. De Andia Y., Święty, Pan, Dawca życia, in Communio 8(1988) no. 1, pgs. 36-39.

11. Dictionnaire des noms communs, des noms propres, precis de grammaire, Paris 1993.

12. Dictionnaire du français, Hachette 1987.

13. Dictionnaire du poche français-polonais et polonais-français, ed. B. Hamel, Warszawa n.d.

14. Encyklopedia Biblijna, ed. P. J. Achtemeier, Warsaw 1999.

15. Katechizm Kościoła Katolickiego, Poznan 1994.

16. Катехизис Католической Церкви, Moscow 1996.

17. Kaczyński M., Tłumaczenie różnych form rzeczowników polskich na język francuski, Lublin 2000.

18. Gądecki S., Wstęp do Pism Janowych, Gniezno 1962.

19. Jakoniuk L.M., The French and Polish Versions of the Catechism of the Catholic Church: An Examination of Certain Passages of the Catechism's teaching on the "Mysterium Ecclesiae" from a Philological and Translational Perspective, RTK XVI/3 (2017), pgs. 317-338.

20. John Paul II, Wierzę w Ducha Świętego Pana i Ożywiciela, Vatican City 1992. 
21. Jan Paweł II, Wierzę w Kościót jeden, święty, powszechny i apostolski, Vatican City 1996.

22. Kielski B., Struktura języków francuskiego i polskiego w świetle analizy porównawczej, Vol. 1, Lodz 1957.

Catechetics

23. Langenscheidt's pocket english dictionary english-polish polish-english, ed. T. Grzebieniowski, n.d.

24. Maty stownik wtosko-polski i polsko wtoski, eds. S. Soja, C. Zawadzka, Z. Zawadzki, Warsaw 1977.

25. Martini C. M., Kościót - jak lepiej go rozumieć, Warsaw 1997.

26. Napieralski M., O nowym Katechizmie. Wprowadzenie w lekture Katechizmu Kościoła Katolickiego, Poznan 1994.

27. Ozorowski E., Wierzę w Ducha Świętego, Bialystok 1998.

28. Podręczna encyklopedia Biblijna, ed. Dąbrowski E., Vol. 1, Poznan 1959.

29. Podręczny stownik francusko-polski z suplementem, eds. Kupisz K., Kielski B., Warsaw 1939.

30. Podręczny stownik rosyjsko-polski, ed. J. H. Dworecki, Warsaw 1986.

31. Schelkle K. H., Teologia Nowego Testamentu. Bóg był w Chrystusie, Vol. 2, Cracow 1984.

32. Sesboué B., Woliński J., Historia dogmatów. Bóg zbawienia, Vol.1, Cracow 1999.

33. Stownik Biblijny, Brepolis 1987.

34. Stownik języka polskiego, ed. M. Szymczak, Vol. 1, Warsaw 1927.

35. Stownik języka polskiego, ed. M. Szymczak, Vol. 2, Warsaw 1927.

36. Stownik języka polskiego, ed. M. Szymczak, Vol. 3, Warsaw 1927.

37. Stownik łacińsko-polski, ed. M. Plezia, Vol. 4, Warsaw, PWN, 1974.

38. Stownik Nowego Testamentu, ed. X. L. Dufour, Poznan 1981.

39. Stownik poprawnej polszczyzny, ed. W. Doroszewski, Warsaw 1980.

40. Stownik teologii biblijnej, ed. X. L. Dufour, Poznan - Warsaw 1982.

41. Stownik wyrazów obcych, Warsaw 1978.

42. Sobór Watykański II: Dokumenty, Dekrety, Deklaracje. Tekst tacińskopolski, Paris 1967.

43. Sobór Watykański II: Konstytucje, Dekrety, Deklaracje, Pallottinum 1968.

44. Szymusiak J., Duch Święty w Kościele wedtug Ojców Kościoła trzech pierwszych wieków, AK, 65 (1973) 1, pgs. 50-57. 